\title{
Entrepreneurship in translator and interpreter training
}

\section{Introduction}

This thematic section focuses on entrepreneurship education in translator and interpreter training. Fostering entrepreneurship has been one of the objectives of the European Union since the Lisbon Strategy (European Council 2000), and one means of achieving this is by mainstreaming it at all levels and all areas of education, including translation and interpreting.

Entrepreneurship can be understood in many ways: from self-employment (QAA 2012) to personal and soft skills development. The European Union (2018) adopts a wide meaning of entrepreneurship and defines entrepreneurship competence as the capacity to act upon opportunities and ideas and transform them into values for others. It is therefore about creativity, critical thinking, problem-solving, perseverance and teamwork.

Choosing a restrictive conception of entrepreneurship - such as self-employment - or a more integrative one - such a self-employment and soft skills development - will have consequences for the teaching model that will be implemented. It is not only a question of including specific contents on how to develop a business plan, but it is also necessary to introduce a new pedagogical approach that entails changes in the combination of specific and soft skills, in the teaching and learning methodologies and in the roles of students and teachers (Lackeus 2015).

In this introduction, we first discuss the initiatives of the European Union to enhance entrepreneurship. Next, we take a look at earlier entrepreneurship studies in the field of translation and interpreting. Finally, we present the articles that make up this thematic issue.

\subsection{Entrepreneurship in the European Union}

The European Commission considers entrepreneurship a key factor for competitiveness and points out that Europe needs more entrepreneurs creating jobs, given the high level of unemployment, the low rate of business start-ups, the high incidence of bankruptcy and the low growth of businesses (Pérez Marco 2013). Therefore, based on the idea that entrepreneurship is a skill that can be learned, the European Commission stresses the importance of education in the development of a business culture at all levels, from primary school to university and beyond. This objective is reflected in the Europe 2020 Strategy, which prioritises fostering entrepreneurship to face the transformation of Europe's economy and to reinforce an economy based on knowledge and innovation.

The Entrepreneurship 2020 Action Plan (European Commission 2020) is the Commission's answer to challenges that have arisen from the recent economic crises and the decline in business vocations. This action plan is a road map for action to exploit the entrepreneurial potential of Europe, remove existing constraints and radically change the entrepreneurial community of the European Union. It intends to promote the emergence of new companies and create a much more favourable environment for the success and growth of existing entrepreneurs, and it identifies entre-

$\begin{array}{lll}* & \text { Anna Kuznik } & \text { Christian Olalla-Soler } \\ \text { Departament de Traducció i Interpretació i- } & \text { Instytut Filologii Romańskiej } & \text { MC2 Lab, Dipartimento } \\ \text { Estudis de l'Assia Oriental } & & \text { di Interpretazione e Traduzione } \\ \text { Universitat Autònoma de Barcelona } & \text { Uniwersytet Wroctawski } & \text { Università di Bologna } \\ \text { E-mail: isabel.galan@uab.cat } & \text { anna.kuznik@uwr.edu.pl } & \text { christian.olalla@unibo.it }\end{array}$


preneurial education as one area for urgent intervention. The Entrepreneurship 2020 Action Plan constitutes the strategic reference framework for the development of education and entrepreneurship policies at a European level.

According to a survey conducted by the European Commission (European Commission 2013), between $15 \%$ and $20 \%$ of students who participate in a mini-company project during secondary school later establish their own businesses. The European Commission also points out that people with entrepreneurial education are more employable and that young people with entrepreneurship education are more likely to set up their own companies. This shows that knowing how to create a business increases the possibility of starting one. In addition, the British Household Survey found that people who have been exposed to entrepreneurial models through family, friends or education are more likely to become entrepreneurs themselves (Kirby 2004; Metcalfe 2013).

EntreComp (Bacigalupo et al. 2016) is the response to promote entrepreneurship education at a pan-European level. It is a European frame of reference for entrepreneurial competence based on three areas, with 15 competences each and a series of learning outcomes. It proposes a broad definition of entrepreneurship that is not restricted to mere business creation, following the definition by the European Union mentioned above: "entrepreneurship as a transversal competence, which applies to all spheres of life: from nurturing personal development, to actively participating in society, to (re)entering the job market as an employee or as a self-employed person, and also to starting up ventures (cultural, social or commercial)" (Bacigalupo et al. 2016: 6). It aims to become a tool for legislative and educational reform that can be used to design and revise curricula.

Clearly, the European Commission is striving to enhance entrepreneurial competence at all educational levels. Universities are urged to be more proactive in their efforts to offer more formal and informal learning opportunities in entrepreneurship. Therefore, many universities, known as entrepreneurial universities, offer facilities for organising workshops on innovation and provide support to students with start-up business ideas. However, we believe that for a university to be truly entrepreneurial, it is not enough to have support facilities for entrepreneurial students because many of those who use these facilities already have entrepreneurial skills when they enter university. For a university to be considered entrepreneurial, it should offer entrepreneurial education to the whole community of students so those who arrive at the university without any entrepreneurial vocation or prior knowledge can acquire the academic and practical competences to become entrepreneurs.

Moreover, entrepreneurship education is usually only embedded in business, science or technology degrees. To enable university students to become entrepreneurs, it is important to address entrepreneurship in all fields of knowledge, but particularly in undergraduate courses and the humanities.

\subsection{Entrepreneurship in translator and interpreter training}

Despite the European strategies adopted to embed entrepreneurial competence in training, insufficient emphasis is being placed on its development in translator and interpreter training and on professional competence in general (Álvarez-Álvarez Álvarez/Arnáiz-Uzquiza 2017; Galán-Mañas 2017; Rodríguez Céspedes 2017; Kuznik 2019).

However, if we take into account the translation and interpreting industry, we can see the importance of integrating entrepreneurship into training. The results of a research survey of the graduates of translation and interpreting (Galán-Mañas 2017) showed that only $15.2 \%$ of them are self-employed, $8.8 \%$ are both employed and self-employed and $2 \%$ have started their own companies. Given that $80 \%$ of translation and interpreting services are outsourced (Kuznik 2010), self-employment accounts for a rather low percentage of graduates. Further research is needed to determine whether the low rates of self-employment are caused by a lack of training in entrepreneurial skills or are due to other causes. 
Several research initiatives study the integration of entrepreneurship into translation and interpreting training. Klimkowski (2015) conducts a study with students to learn their opinions on different aspects of entrepreneurship and highlights the importance of entrepreneurship education. Gieure (2016) analyses the entrepreneurship education offered in translation courses in Spain. Rodríguez Céspedes (2017) describes a programme designed to improve employability and enterprise skills at the master of arts level, while Galán-Mañas (2017) presents some proposals to encourage entrepreneurship in a professionalization programme. Buysschaert et al. (2018) present an initiative to simulate translation agencies in the classroom. In 2018, Galán-Mañas (2018) proposes curricular and extracurricular activities with four levels of progression that correspond to each of the courses of a bachelor of arts degree. Olalla-Soler (2019) presents a mentoring program with freelance translators and interpreters in which students not only have to translate, but also must deal with taxation, client search, code of conduct or ergonomics.

In sum, we argue that entrepreneurship education should be embedded in translation and interpreting programmes because it can have an impact on the employability of individuals in a number of ways: better job-seeking skills, less probability of being unemployed, more confidence to become self-employed and higher income.

\section{The articles of the thematic section}

The articles in this section address different issues related to entrepreneurship education in translation and interpreting. There are 11 articles from six European countries: Finland, France, Poland, Spain, the Netherlands and the United Kingdom.

Klimkowska and Klimkowski open the section by presenting results of their research on how 436 Polish students in full-time translation courses perceive their future professional functioning from hard- and soft-skill perspectives. The diagnostic procedure developed in the article can be useful to translation curricula designers and teachers in getting to know what their students think about being entrepreneurial translators. A list of suggested didactic activities to exemplify such interventions is also provided.

The aim of the paper by Muñoz-Miquel is to put forward a series of teaching proposals aimed at promoting entrepreneurial competence. After presenting the results of an exploratory study of Spanish students' views of the profession, Muñoz-Miquel proposes some activities that are considered particularly useful for fostering entrepreneurial competences.

Veiga Díaz reviews the entrepreneurship competences included in the curricula of undergraduate translation and interpretation degrees in Spain to determine whether they explicitly or implicitly match the competences in the EntreComp framework. Her review reveals that the EntreComp entrepreneurial competences are underrepresented in current curricula in Spain, with some remarkable exceptions, though particularly regarding the 'resource management' and 'learning by doing' competences. The results derive from a SWOT analysis of the collected data and suggest that the identified strengths and opportunities can compensate for most of the weaknesses.

Cuadrado-Rey and Navarro-Brotons' paper focuses on a proposal to improve employability and foster entrepreneurship among graduates of the master's degree in institutional translation at the Universidad de Alicante, Spain. This proposal is based on a large-scale survey that gathered data on the abilities and competences needed for entering the labour market and develop entrepreneurial initiatives according to 133 graduates of the master's degree in institutional translation. The resulting proposal offers comprehensive training to improve employability and foster entrepreneurship and takes into account the training gaps identified by the graduates.

The article by Van Egdom, Konttinen, Vandepitte, Fernandez-Parra, Loock and Bindels describes the entrepreneurial activities carried out within the simulated translation bureaus of the members of the International Network of Simulated Translation Bureaus (INSTB) and shows that participating in simulated translation bureaus has a positive effect on students' entrepreneurial self-efficacy and competence. 
Salo, Veivo and Salmi's contribution addresses translation students' pre-professional identity as an emerging professional identity of translators. They examine self-reflective essays written by translation students who participated in a translation business simulation during their master's degree course in translation studies at the University of Turku, Finland. The authors observed that experiential learning that fosters real practice and teamwork such as translation business simulations helps students develop their professional identity in terms of who they are as future professionals and how they fit into the professional community.

Aguirre and Guindal present a didactic proposal for interpreting based on the Blue Ocean Strategy and the flipped learning teaching methodology in the degree of translation and interpreting at Universidad Pontificia Comillas. The authors conducted an experimental study that shows that this methodology helps students create their own innovative market space and realise they can fulfil clients' expectations without compromising profitability and decent working conditions.

Morón's article is about a transcreation project carried out with translation and interpreting students at Universidad Pablo de Olavide. The aim of the project is to simulate real transcreation professional practice to fulfil current professional profiles. As the author states, this type of practice not only enhances technical and professional transferable skills such as creativity, emotional intelligence, decision-making and problem-solving, but it also involves adopting new interdisciplinary profiles. Thus, it favours employability opportunities outside the translation field.

Muñoz-Miquel, Montalt and García-Izquierdo's article presents an exploratory study in which, by means of a survey, they identified the tasks undertaken by professional medical translators. Since the tasks that professionals have to deal with are so diverse, the authors propose some teaching activities to encourage versatility in the master's degree in medical and healthcare translation at the Universitat Jaume I. This methodology, the authors state, gives future graduates a new interdisciplinary and interprofessional perspective.

Martín-Ruel claims that social entrepreneurship in the field of international protection and refugees is a potentially viable employment opportunity. As the ever-growing numbers of asylumseekers arriving in Spain have a recognised right to access translation and interpreting services, the author finds it necessary to advocate the training of interpreters to operate in asylum scenarios and meet the specific deontological requirements involved therein. The author presents results of a series of interviews conducted with refugee reception organisations in the province of Seville and finds that the application of professional ethics in real-case situations is indeed very often deficient, and its inclusion in training syllabuses in Spain could help address this social need.

Ginovart presents a study on professional profiles related to machine translation and post-editing. She posits that knowing these profiles will allow improvement of the training to meet the future trends in the market and will take into account these technological profiles in translation programmes as well as unleashing new business opportunities.

This thematic section would not have been possible without the collaboration of all the authors and reviewers, whose expertise has helped ensure that academic standards are met. We thank them all for their valuable contributions.

\section{References}

Álvarez-Álvarez, Susana/Arnáiz-Uzquiza, Vanesa 2017: Translation and Interpreting Graduates under Construction: Do Spanish Translation and Interpreting Studies Curricula Answer the Challenges of Employability? In The Interpreter and Translator Trainer 11 (2-3), 139-159.

Bacigalupo, Margherita/Kampylis, Panagiotis/Punie, Yves/Van den Brande, Godelieve 2016: EntreComp: The Entrepreneurship Competence Framework [online]. https://publications.jrc.ec.europa.eu/repository/bitstream/JRC101581/ lfna27939enn.pdf (accessed 9 February 2020).

Buysschaert, Joost/Fernandez-Parra, Maria/Kerremans, Koen/Koponen, Maarit/van Egdom, Gys-Walt 2018: Embracing Digital Disruption in Translator Training: Technology Immersion in Simulated Translation Bureaus. In Revista Tradumàtica 16, 125-133. 
European Commission 2020: Entrepreneurship Education. Internal Market, Industry, Entrepreneurship and SMEs [online]. https://ec.europa.eu/growth/smes/promoting-entrepreneurship/support/education_en (accessed 9 February 2020).

European Union 2018: Council Recommendation of 22 May 2018 on Key Competences for Lifelong Learning (Text with EEA Relevance.) [online]. In Official Journal of the European Union C 189/1, 4.6.2018, 1-13. https://eur-lex. europa.eu/legal-content/EN/TXT/?uri=uriserv\%3AOJ.C_.2018.189.01.0001.01.ENG\&toc=OJ\%3AC\%3A2018\%3 A189\%3ATOC (accessed 9 February 2020).

European Commission 2013: Entrepreneurship education needs to be boosted. Memo 13/77 [online]. https://ec.europa. eu/commission/presscorner/detail/en/MEMO_13_77 (accessed 15 December 2019).

European Council 2000: Lisbon European Council 23 and 24 March 2000. Presidency Conclusions [online]. https:// www.europarl.europa.eu/summits/lis1_en.htm (accessed 15 December 2019).

Galán-Mañas, Anabel 2017: Programa para la mejora de la empleabilidad de los egresados en Traducción e Interpretación. Un estudio de caso. In Conexão Letras 17, 154-171.

Galán-Mañas, Anabel 2018: Aprender a emprender en el grado de Traducción e Interpretación. In Tanagua Barceló, María/Velasco, Carmen (eds.), Evaluación, direccionalidad y orientación profesional en los estudios de Traducción e Interpretación. Madrid: EDA Libros, 33-55.

Gieure, Clara 2016: El traductor e intérprete emprendedor: análisis de la supervivencia de las empresas y los empresarios autónomos. PhD dissertation. Universidad de Alicante.

Kirby, David A. 2004: Entrepreneurship Education: Can Business Schools Meet the Challenge? In Education and Training 46 (8/9), 510-519.

Klimkowski, Konrad 2015: Entrepreneurial training in translator and interpreter education. In Roczniki Humanistyczne $63(11), 67-83$.

Kuznik, Anna 2010: El contenido de los puestos de trabajo de los traductores. El caso de los traductores internos en las empresas de traducción de Barcelona. $\mathrm{PhD}$ dissertation. Universitat Autònoma de Barcelona. [online]. http:// tdx.cat/handle/10803/5279 (accessed 9 February 2020).

Kuznik, Anna 2019: Entre la traduction intralinguale et intersémiotique. L'innovation dans les services de traduction vue par les responsables des entreprises de traduction françaises. In Meta 64 (1), 194-214.

Lackeus, Martin 2015: Entrepreneurship in Education. What, Why, When, How [online]. https://www.oecd.org/cfe/ leed/BGP_Entrepreneurship-in-Education.pdf (accessed 9 February 2020).

Metcalfe, Robert 2013: Can Entrepreneurship Be Taught? In Texas Education Review 1 (1), 119-131.

Olalla-Soler, Christian 2019: Bridging the Gap between Translation and Interpreting Students and Freelance Professionals. The Mentoring Programme of the Professional Association of Translators and Interpreters of Catalonia. In The Interpreter and Translator Trainer 13 (1), 64-85.

Pérez Marco, Belén 2013: Plan de acción sobre emprendimiento 2020. Una revolución cultural. In Anales de mecánica y electricidad 20, 39-43.

QAA 2012. Entreprise and entrepreneuship education: Guidance for UK higher education providers. Gloucester: The Quality Assurance Agency for Higher Education. [online]. https://www.qaa.ac.uk/docs/qaas/enhancement-anddevelopment/enterprise-and-entrpreneurship-education-2018.pdf?sfvrsn=15f1 f981_8 (accessed 9 February 2020).

Rodríguez Céspedes, Begoña 2017: Addressing Employability and Enterprise Responsibilities in the Translation Curriculum. In The Interpreter and Translator Trainer 11 (2-3), 107-122. 